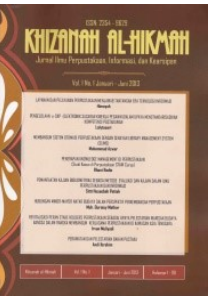

\title{
A BIBLIOMETRIC STUDY TOWARDS THE APPLICATION OF HERBS IN AN ACADEMIC ENVIRONMENT
}

\author{
Rita Nursuhaila Ridzuan*, Nurulwahidah Fauzi*, Robiatul Adawiah \\ Amat*, Nor Zulaili Mohd Ghazali*
}

Pengutipan: Ridzuan, R. N., Fauzi, N., Amat, R. A., \& Ghazali, N. Z. M. (2019). A bibliometric study towards the application of herbs in an academic environment. Khizanah al-Hikmah : Jurnal Ilmu Perpustakaan, Informasi, dan Kearsipan, 7(1), 23-37. DOI: 10.24252/kah.v7i1a3.

*Faculty of Quranic and Sunnah Studies, Universiti Sains Islam Malaysia Email:wahidah@usim.edu.my

(Submitted: 01-11-2018, Revised: 07-02-2019, Accepted:01-04-2019)

\begin{abstract}
ABSTRAK: Herbal adalah tumbuhan yang mempunyai nilai dari segi perobatan, khasiat makanan, perasa dan aromanya dan ia merupakan satu khazanah alami yang sangat bernilai. Dalam perobatan melayu tradisional, herbal sangat penting dalam mengobati penyakit dan menyelesaikan masalah yang dihadapi oleh, baik mereka yang sehat ataupun yang sedang dalam keadaan sakit. Artikel ini merupakan kajian bibliometrika yang menganalisis kajian akademik terkait herbal, sekaligus menjadi patokan dalam mengetahui produktivitas penelitian. Artikel ini mempunyai beberapa objektif penting yaitu : 1) mengkaji konsep bibliometrika terhadap pengaplikasian herbal yang terdapat dalam kajian akademik, 2) mengkaji jenis-jenis penerbitan kajian akademik yang mengkaji tentang herbal, 3) menganalisis perkembangan disiplin-disiplin ilmu yang terlibat dalam kajian herbal. Dalam kajian ini, penulis telah menggunakan metode kuantitatif dan analisis untuk mengukur tahap produktivitas dengan melihat sumbangan dan peranan penghasilan karya ilmiah dalam bidang ini. Kajian ini penting untuk dipahami agar dapat menjadi satu ukuran bagi ahli akademik dalam bidang keilmuan.
\end{abstract}

Kata kunci: Bibliometrika; herba; perobatan Melayu; kajian akademik

ABSTRACT: Herbs are plants and very valuable as a food, flavonoid, medical, nutrition food and perfume. In traditional folklore, especially within a Malay people, herbs are very important in treating the disease and resolve problems faced by people who are unhealthy. The application of bibliometric study applied to analyze the progress of the article based on a specific discipline, which can be the benchmark of a productivity research. This article seeks to achieve some of important objectives, namely 1) to review the concept of bibliometric towards the application of herbs contained in academic/scientific papers, 2) to examine the types of publishing scientific papers which studying about herbs, 3) to analyze the growth of the disciplines of knowledge involved in the study of herbs. This study will use quantitative methods and analysis of inductive and deductive method to measure the phase of productivity by looking at the contribution and role of the scientific papers in this field. The results of a study undertaken by the authors find that there are only a few researches undertaken related about herbs mentioned in scholarly works that have not been studied extensively by researchers.

Keywords: Bibliometric; herbs; Malay medicine; scientific works

\section{INTRODUCTION}

The production of scholarly works by academics helps society discover, use and build upon a wide range of knowledge through a powerful research and teaching platform and preserve this knowledge for future generations. In addition, the knowledge and experience documented could 
be a catalyst for writing activities in academic environment (Omar, 2007:1). The effort of the publishing and writing project will make a lifelong learning in knowledge-oriented societies can be implemented. It is also a platform for all information whether in the fields of economy, medicine, culture, health, nutrition, environment and social.

Since the genres of writing in presenting herbal data from this bibliometric point of view have not yet been shown in the references of society, especially in the academic world, therefore in this study, the authors intend to present the analysis with quantitative and statistical analysis methods. This is because evaluation of bibliometrics methods can determine the influence of a publication in terms of its works or writers and can describe the relationship between two or more writers. According to Glanzel (1999) elaborated that bibliometric analysis in fact has become a standard tool of science policy and research management in the last decades $(\mathrm{Hj}$ Zainal, 2008:17). This research will be an indicator of research productivity, research trends and emphasis given to research in various disciplines such as publication quantity, popular subject and research quality, to evaluate academic performance. The purpose of this study is to analyze the progress of articles according to research discipline or research field in more specific form.

\section{PREVIOUS FINDINGS}

Herbs according to The Third Edition of The Dictionary Board is a plants used for food, medicine, flavoring or fragrances for their savory or aromatic properties. In botanical English, the word "herb" is also used as a synonym of "herbaceous plant". This means that it is not just a shrub plants even woody trees can also be defined as herbs if there is potential for any of these three uses (Mat Amin, 2015:23). According to Herb Trade Association (1976), the term of herb is also defined as a plant, parts of plants or plant extracts which are used for medicinal purposes. The World Health Organization (WHO) estimates that up to four billion people representing $80 \%$ of the world's population depends on traditional medicine as a primary source of healthcare which involves the use of herbs for rehabilitation, treatment and healthcare (Plate \& Srinivasan, 1997:68-74). In China, India and Africa are well-known as herbal medicine practitioners where the group is one of the largest producers and consumers of herbal treatments in the world. In Malaysia it is estimated that nearly 1230 species of which are $8 \%$ of herbaceous herbs used as herbal medicines (Soepadmo, 1999:34).

History has also proven that many benefits from herbs for medical purposes. Islamic scientists and scholars also state that the purpose of using herbs not only constitutes the primary components to cure the disease but also makes the body in a healthy condition. In fact, Al-Riyasi Ibn Jarit, Egyptian ancestor and physician to Sultan Salahuddin Al Ayubi has written two books about lime and rubab and its uses (Hobbs, 2017). Ibn al-Bayțār from Malaga wrote two books on medicinal plants in Kitāb Mughinifi al-adawiyah al-Mufradah (Medicinal Herbs) and Kitab al-Jami'fi al-Adawiyah al-Mufradah (Compendium on Simple Medicaments and Foods). Another ancient record of herbs used has indicated the use of chaulmoogra oil obtained from species of Hydrocarpus gaertn for the treatment of leprosy that was recorded in the pharmacopoeia of the Emperor Shen Nung of Chinese between 2730-3000 BC (Sallau, 2009:21). In the Qur'an and hadith there is also mention of the uses of plants, for example, in the Qur'anic texts expressed through the words i) shajara (tree) and also ii) nabata (grows) as 50 times, for instance in surah Fatir verse 13, surah al-Nisa verse 124, surah al-Isra verse 71 and so forth. In surah Fatir verses 13 Allah s.w.t said:

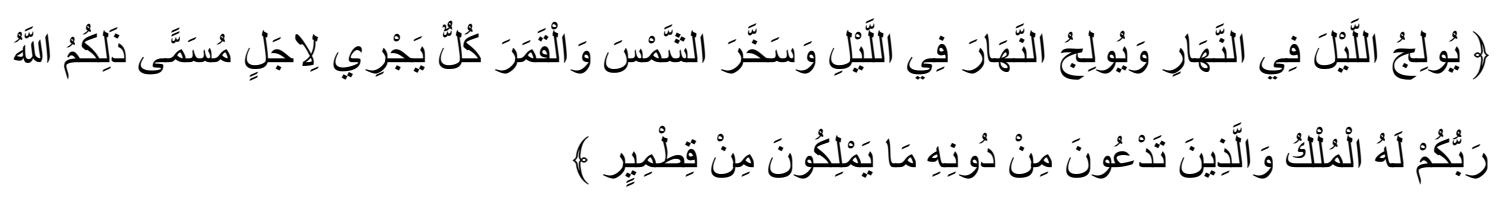

Meaning: "He causes the night to enter the day, and He causes the day to enter the night and has subjected the sun and the moon-each running (its course) for a specified term. That is Allah, your Lord; to Him belongs sovereignty. And those whom you invoke other than Him do not possess (as much as) the membrane of a date seed" (35:13). 
In the Quran, there are several other types of plants and herbs was mentioned as grapes

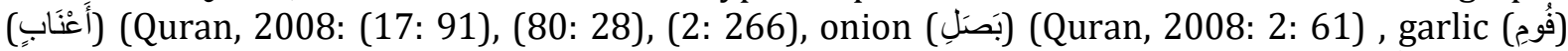
(Quran, 2008: 2: 61), mustard seed (خَرْدَ) (Quran, 2008: (21: 47), (31: 16).), fig (التِنِيَّ) (Quran,

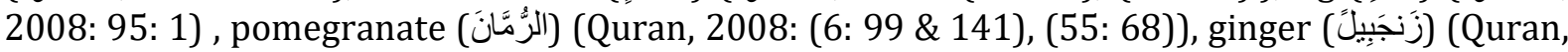
2008: 76: 17) and others. Certainly plants specifically mentioned in the Quran, has its own advantages and benefits. In the Qur'an and hadith also mentioned the usefulness of plants, such as hadiths related to the use of al-Habbat al-Sawda (Black Cumin) (Sahih al-Bukhari: 591). The hadith narrated by Khalid bin Sa'd: We went out and Ghalib bin Abjar was accompanying us. He fell ill on the way and when we arrived at Medina he was still sick. Ibn Abi 'Atiq came to visit him and said to us, "Treat him with black cumin. Take five or seven seeds and crush them (mix the powder with oil) and drop the resulting mixture into both nostrils, for 'Aisha has narrated to me that she heard the Prophet (4aying, 'This black cumin is healing for all diseases except As-Sam.' Aisha said, 'What is As-Sam?' He said, 'Death."

In addition, Islamic scholars also state that the purpose of using herbs is to restore the body's balance and curing the disease. According to Ibn Sina's theory in The Canon of Medicine the level of herbal function is:

1. Detoxification: The process of removing toxic substances or qualities in the body.

2. Relaxation: Placing the body in a stable state where the condition of temperature, alkali, acid are at the best possible level in order to help the function of the immune system.

3. Renew/Reproduce: Dead and damaged cells are replaced with new ones, where herbs with antioxidants can act to prevent degenerative diseases.

4. Move/Change: Restoring the function, that is, after the above process runs perfectly, the organs will function normally.

\section{Malay Traditional Medicine}

Malaysia is a multicultural country that has rich traditional practice modalities with herbal medicines among Malay communities. It is also proven by the discovery of various materials and manuscripts related to Malay traditional medicine manuscript known as Kitab Tib. The importance of the manuscripts related Kitab Tib has been emphasized with the development of medical science and practice of traditional medicine, especially among the Malay archipelago. There are more than 40 copies of the Kitab Tib with various titles located at the Centre of Malay Manuscript in National Library of Malaysia (PNM, 2017).

The field of medicine and healthcare is one of the newest and fastest growing disciplines. Traditional Malay medicine has an exclusive system in terms of the concepts of disease, diagnose, treat, cure, abstinence and how to avoid the illness. Similarly, treatment methods, ingredients and manufacturing process of the medicines, the terms used and other aspects of the whole. Additionally, an interesting aspect of Malay traditional medicine is the use of herbs as a medicinal ingredient and treatment for various diseases. These ingredients include various types of herbs, medicinal plants and other living things either animate or inanimate. The best example is the name of the plant, of the type of tree, shrub, herbs and others. There is also disclosed for specific parts used, including stems, roots, tubers, content, shoots, bark, leaves, buds, or the whole tree. These plants are given a distinctive name, different from one to another and most of them can be adjusted with the term of botanical or scientific names identical in most texts in this sub-genre (Mat Piah, 2012:6).

\section{RESEARCH METHODOLGY}

This study used a bibliometric method to analyze the progress of the article on herbs used in traditional Malay medicine which can be the benchmark of a productivity research. Bibliometrics is statistical analysis of written publication such as books or articles (OECD, 2012). Bibliometric analysis is not only often used in the field of library and information science but it is also used in other fields such as scientometrics to provide quantitative analysis of academic literature or for evaluating budgetary spending. Besides that, citation analysis is a commonly 
used bibliometric method which is based on constructing the citation graph, a network or graph representation of the citation between documents (Hertzel, 2003:288-328). The British Standard Institution defines bibliometrics as 'the study of the use of documents and patterns of publication in which mathematical and statistical methods'. Thus, the purpose of bibliometric analysis is to quantify, compare and communicate the importance of your scientific work. Moreover, bibliometrics data will increase the visibility and impact of research, identifying the most suitable journals for publication, identifying potential collaborators and areas for research and others (Sulistyo-Basuki, 2002:13-15).

Therefore, the main objective of the bibliometric study is to measure academic and research works that have been published in scientific journals. The development publication also helps in obtaining data and information in bibliometric analysis (Ahmad, Monika, \& Yakob, 2016). Pitchard in 1969 explained bibliometrics as "the application of mathematical and statistical methods to books and other media of communication". This definition expands the scope of bibliometric to various media not only to books and scientific journal only (Pitchard, 1969:348349).

In applying this bibliometric method, search methods are important to ensure that any data on the research can be found effectively. From a search in keywords, the authors found research and scientific works on herbs and traditional Malay medicine through articles, books, magazines, thesis, dissertation, journal and others. Search keywords are as follows:

Table 1: The technique to obtain data

\begin{tabular}{cl}
\hline No & \multicolumn{1}{c}{ Keyword Search } \\
\hline 1. & Herbs \\
2. & Herbs and Plant \\
3. & Herbal Treatment \\
4. & Traditional Medicine \\
5. & Medicinal Plant \\
\hline
\end{tabular}

The search keyword to get data is generated through the process of screening and initial reading of articles on the topics of study which is to ensure that the findings comply with the features of the publication of journals and academic materials. Duration of data collection is limited to 2 decades to examine the development of productivity writing on herbs. Some of the databases used as sources for obtaining and identifying herbal data are MyTO:Malaysia Theses Online, Malaysian Academic Library Union Catalog, Google Sholar, Academia.edu, National Library of Medicine (NLM) dan National Agricultural Library (NAL). After all the data is collected, it will be scanned manually and classified using Microsoft Office Excel.

\section{RESULTS AND FINDINGS ANALYSIS}

In this bibliometric study, the authors have been focusing on herbs in which this production data will be the main reference data for academic or herbalist regarding the study of herbs that have been studied. This study will focus on two items to be analyzed:

1. The types of publishing scientific papers which studying about herbs

2. The disciplines of knowledge involved in the study of herbs 


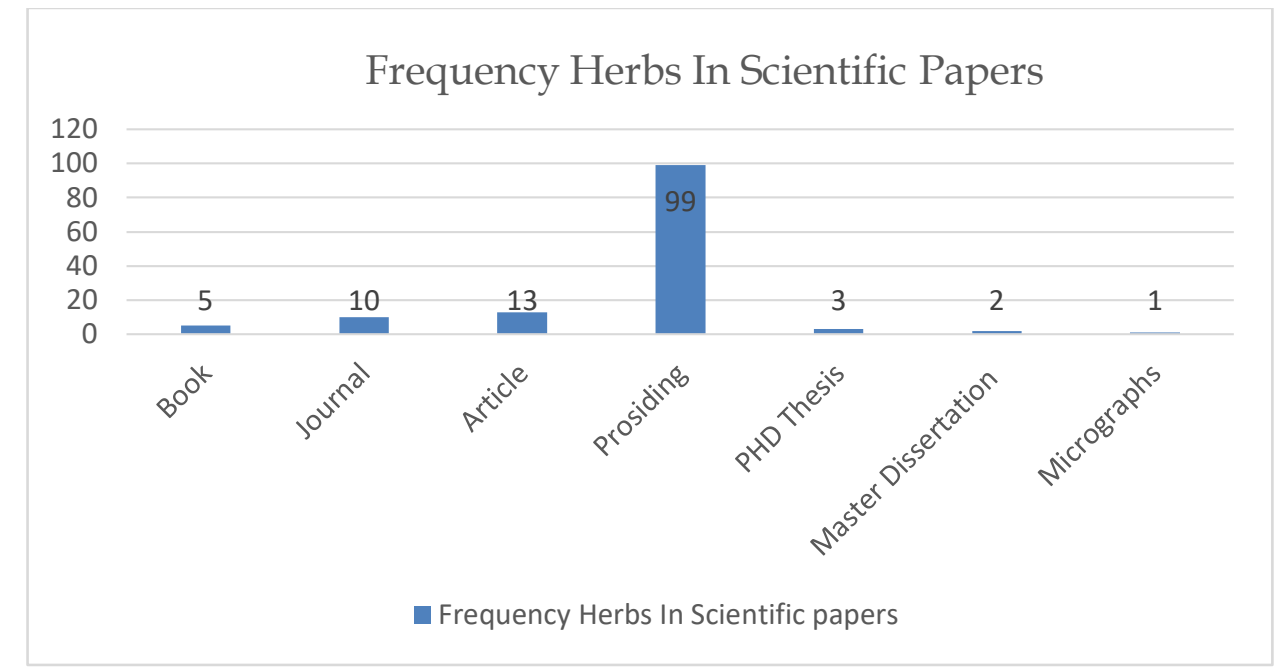

Figure 1. Frequency herbs in scientific papers

Referring to the clustered column above, the results of previous research on herbs found that majority of study are dominated by procedings by $74 \%$. Articles were in the second highest percentage of $9.7 \%$. This was followed by a journal with the percentage of $7.5 \%$ and book by $3.7 \%$. The lowest percentage recorded $\mathrm{PhD}$ thesis with the percentage $2.2 \%$, master dissertation by $1.5 \%$ and micrographs by $0.75 \%$. List of materials related publications herbs can be examined through the following table:

List of Publishing Scientific Papers and Disciplines of Knowledge about Herbs

\begin{tabular}{|c|c|c|}
\hline \multicolumn{2}{|r|}{ Book } & \multirow{2}{*}{$\begin{array}{c}\begin{array}{c}\text { Disciplines Of } \\
\text { Knowledge }\end{array} \\
\text { Agriculture }\end{array}$} \\
\hline 1. & Agro-Techniques of Selected Medicinal Plants (2008) & \\
\hline 2. & $\begin{array}{l}\text { Herbal Medicine Biomolecular and Clinical Aspects } \\
\text { (2011) }\end{array}$ & $\begin{array}{l}\text { Herbal and Traditional } \\
\text { Medicine }\end{array}$ \\
\hline 3. & $\begin{array}{l}\text { WHO Monographs on Selected Medicinal Plants Vol1- } \\
\text { Vol4 (1999) }\end{array}$ & $\begin{array}{l}\text { Herbal and Traditional } \\
\text { Medicine }\end{array}$ \\
\hline 4. & Prophetic Medicine and Herbalism (2014) & Islamic Studies \\
\hline 5. & Warisan Perubatan Melayu & $\begin{array}{l}\text { Herbal and Traditional } \\
\text { Medicine }\end{array}$ \\
\hline \multicolumn{2}{|r|}{ Journal } & $\begin{array}{l}\text { Disciplines of } \\
\text { Knowledge }\end{array}$ \\
\hline 1. & $\begin{array}{l}\text { A Novel Heptacyclic Diterpene From Alipinia } \\
\text { Pahangensis Ridley, A Wild Ginger Endemic To Malaysia. } \\
(2014)\end{array}$ & Chemistry \\
\hline 2. & $\begin{array}{l}\text { Antioxidant And Antibacterial Activities of Flavonoids } \\
\text { and Curcuminoids From Zingiber Spectabile Griff. (2012) }\end{array}$ & $\begin{array}{l}\text { Food Science } \\
\text { Technology }\end{array}$ \\
\hline 3. & $\begin{array}{l}\text { Anti-Allergic Activity of Some Selected Plants In The } \\
\text { Genus Boesenbergia And Kaempferia (2011) }\end{array}$ & Botanical \\
\hline 4. & $\begin{array}{l}\text { Antioxidant Activities and Cyctotoxicity of Zingiber } \\
\text { Zerumbet (L.) Smith Rhizome (2013) }\end{array}$ & Botanical \\
\hline 5. & $\begin{array}{l}\text { Antioxidant Properties of Selected Etlingera and Zingiber } \\
\text { Species (Zingiberacea From Borneo Island. (2012) }\end{array}$ & Biological Science \\
\hline
\end{tabular}




\section{Chemical Composition and Antibacterial Activities Essential Oil From Zingiber Spectabile Griff (2012) \\ 7. Essential Oils Of Zingiber Officinale Var.Rubrum Theilade And Their Antibacterial Activities. (2010) \\ 8. Significance of Gingers (Zingiberacea) In India System Of Medicine - Ayurveda : An Overview (2013) \\ 9. Zingiber Officinale : A Natural Gold (2011) \\ 10. Zingiber Skornickovae, A New Species of Zingiberaceae From Central Vietnam \\ 11. Study Medicinal Plants in Holy Quran (2014)}

\author{
Chemistry \\ Biological Science \\ Chemistry \\ Biological Science \\ Medicine \\ Biological Science \\ Botanical \\ Islamic Studies
}

\section{Article \\ Disciplines of Knowledge}

1. Cultural Studies In Ornamental Ginger. (2002)

2. Ginger (Zingiber Officinale) (1999)

3. Medicinal Properties of Ginger (Zingiber Officinale Rosc.) (2003)

4. Potting Ornamental Ginger (2001)

5. Thai Zingiberaceae: Species Diversity and Their Uses. (1999)

6. Three New Species Of Scaphochlamys (Zingiberaceae) From Peninsular Malaysia (2005)

7. Herbal Treatment And Home Remedies Of Dengue (2015)

8. Herbal Manual : The Medicinal. Toilet, Culinary And Other Uses of 130 of The Most Commonly Used Herbs (1936)

9. History Of Use Of Traditional Herbal Medicines (2004)

10. Health And Medicine In The Islamic Tradition Based On The Book Of Medicine (Kitab Al-Tib Of Sahih Al-Bukhari (2006)

11. Perbandingan Tumbuh-Tumbuhan Dalam Gaya Bahasa Al-Quran Al-Karim (2015)

12. Anatomi Sistematik Pada Anggota Familia Zingiberaceae (2001)

13. Useful Medicinal Flora Enlisted in Holy Quran and Ahadith (2009)
Botanical

Botanical

Pharmacology

Algriculture

Food Science

Technology

Botanical

Biological Science

Forest Research

Pharmacology

Herbal and Traditional Medicine

Herbal and Traditional Medicine

Medicine

Islamic Studies

Herbal and traditional Medicine

Biological Science

Islamic Studies

\section{Proceedings}

1. Tongkat Ali : From Lab To Market.

2. Analyzing Malay Medical Manuscript Mss 2999 The Findings And The Hope For The Future.

3. Commercialized Innovative Herbal Products From UPM

4. Development Of Herbal Product For Cancer Theraphy

5. Physio-Chemical Properties Of Spray Dried Clinacanthus Nutans Extract.

\section{Disciplines Of}

Knowledge

Herbal and Traditional Medicine Medicine

Islamic Studies

Herbal and Traditional Medicine

Herbal and Traditional Medicine

Chemistry Medicine 
6. Extraction Of Antioxidants From Leaves Of Clinacanthus Nutans Lindau : Effects of Extraction Method And Solvent

7. Anti-Proliferative Effect Of Clinacanthus Nutans On Ovarian, Breast And Colorectal Cancer Call Lines.

8. Detection Of Irradiated Herbs Using Photo-Stimulated Luminescence Technique.

9. Optimization Of Antioxidant Activity In Clinacanthus Nutans

10. Effects Of Equal Doses Of Sulforaphane, Curcumin And Quercetin On Heme Oxygenase 1 Gene Expression In Mice Liver

11. Evaluation Of Antimicrobial And Antioxidant Properties Of Anethum Araveolens Leaf Extracts

12. Asam Gelugur Powder Rich In HCA (Hydroxycitric Acid : A Potential Crop For Weight Management

13. Toxicology Study Of Hibiscus Sabdariffa L.Leaves Extract On Normal Sprague-Dawley Rats

14. Clinacanthus Nutans L : Safety And Toxicity Study

15. In Vito Toxicological Evaluation Of 50 Methanol Extracts From Traditional Medicinal Plants Used By The Orang Asli

16. Toxicity Study Of Sarawak Wild Pepper Root (Piper Arborescens

17. In Silico Prediction Of Drug Likeness And Admet Properties Of Some Centella Compounds

18. Nutrigenomics Effects Of Curculigo Latifolia On Type 2 Diabetic Model

19. Protein Expression Pattern In Swietenia Macrophylla Seed

20. Proteome Profiles Of Seeds From Swietenia Macrophylla After Cold Storage

21. Effect Of PH On Adsorption Of Organic Acid And Phenolic Compounds In Noni

22. Effect Of Organic-Based Fertilizer Rate And Planting Distance On Biomass Yield Of Belalai Gajah (Clinacanthus Nutans)

23. The Effect Of Packaging Technique On Quality Of Dried Mas Cotek (Ficus Deltoidea

24. Potential Of Medicinal Plants Used By The Jakun People As Antituberculosis Agnets

25. Medicinal Plants Used For Women's Healthcare Among The Jakun Community In Kg. Peta : A Preliminary Study

26. Kaempferia L: Herbs And Ornamental Potential Of Zingiberacea Species

27. Distribution Of Herbs Cultivation In Peninsular Malaysia

28. Halal Herbal Product Integrity Risk Through Supply Chain : A Conceptual Study

29. Consumer Preferences In Selecting Herbal Products

\section{Medicine}

Medicine

Biological Science

Agriculture

Biological Science

Agriculture

Food Science

Technology

Pharmacology

Medicine

Food Science

Technology

Food Science

Technology

Food Science

Technology

Food Science

Technology

Forest Research

Forest Research

Forest Research

Medicine

Forest Research

Forest Research

Chemistry

Food Science

Technology

Food Science

Technology

Horticulture Research

Horticulture Research

Biological Science

Herbal and Traditional

Medicine

Biological Science

Herbal and Traditional

Medicine

Herbal and Traditional

Medicine

Forest Research

Agriculture

Forest Research 
30. Consumer's Perception Towards Local Herbal Supplement Products

31. The Importance Of Long-Term Relationship For The Sustainability Of Malaysian Herbal Industry (2015)

32. Integrating Traditional And Complementary Medicine Into National Health Care (2004)

33. Can Traditional Medicine Coexist With Modern Medicine In The Same Health Care System? (2004)

34. Clinical Trials For Herbal Extracts (2004)

35. Herbal Medicine : Criteria For Use In Health And Disease (2004)

36. Effect of Phytochemicals In Chinese Functional Ingredients On Gut Health. (2004)

37. Tea And Health (2004)

38. Ginkgo Biloba : From Thaditional Medicine To Molecular Biology (2004)

39. Ginger (2004)

40. Lingzhi Polyphorus Fungus (Ganoderma Lucidum) (2004)

41. Epimedium Species (2004)

42. Lingusticum Chuangxiong Hort (2004)

43. Salvia Miltiorrhiza (2004)

44. Schsandrin B And Other Dibenzocyclooctadiene Lignans (2004)

45. Spirulina : An Overview (2004)

46. Averrhoa Bilimbi (2004)

47. Lentinus Edodes : Shiitake Mushrooms (2004)

48. Cruciferous Vegetables And Chemoprevention: The Mechanism of Isothiocyanate-Mediated Chemoprotection In Humans (2004)

49. Rosemary (2004)

50. Crataegus(Hawthorn) (2004)

51. Resveratrol : The Promise Therein. (2004)

52. Pharmacological And Physiological Effects Of Gingseng (2004)

53. Antioxidant Activities Of Prickly Pear Copuntia Ficus Indica Fruit And Its Betalains : Betanin And Indicaxanthin (2004)

54. Antioxidant Activity And Antigenotoxicity Of Cassia Tora (2004)

55. Sho-Saiko-To (2004)

56. Licorice Root Flavonoid Antioxidants Reduce LDL
Agriculture

Agriculture

Herbal and Traditional Medicine

Herbal and Traditional Medicine

Herbal and Traditional Medicine

Herbal and Traditional Medicine

Herbal and Traditional Medicine

Herbal and Traditional Medicine

Herbal and Traditional Medicine

Herbal and Traditional Medicine

Herbal and Traditional Medicine

Herbal and Traditional Medicine

Herbal and Traditional Medicine

Herbal and Traditional Medicine

Herbal and Traditional Medicine

Herbal and Traditional Medicine

Herbal and Traditional Medicine

Herbal and Traditional Medicine

Herbal and Traditional Medicine

Herbal and Traditional Medicine

Herbal and Traditional Medicine

Herbal and Traditional Medicine

Herbal and Traditional Medicine

Herbal and Traditional Medicine

Herbal and Traditional Medicine

Herbal and Traditional Medicine

Herbal and Traditional 
Oxidation And Attenuate Cardiovascular Disease (2004)

57. Estrogen-Like Activity Of Licorice Root Extract And Its Constiturnts (2004)

58. Protection Of Oxidative Brain Injury By Chinese Herbal Medicine (2004)

59. Eurycoma Longifolia Jack (Tongkat Ali) (2004)

60. The Biological \& Pharmacological Properties Of Cordyceps Sinensis, A Traditional Chinese Medicine, That Has Broad Clinical Applications (2004)

61. Phytochemistry, Pharmacology And Health Effects of Brandisia Hancei (2004)

62. Ephedra (2004)

63. Echinacea And Immunostimulation (2004)

64. Medical Attributes Of St.John's Wort (Hypericum Perforotum) (2004)

65. Therapeutic Potential of Curcumin Derived From Turmeric (Curcuma Longa) (2004)

66. Extracts From The Leaves Of Chromolaena Odorata (2004)

67. Medicinal Properties Of Eucommia Bark And Leaves (2004)

68. Systematic Reviews Of Herbal Medicinal Products : Doing More Good Than Harm (2004)

69. Us Of Silicon-Based Oligonucleotide Chip In Authentication Of Toxic Chinese Medicine (2004)

70. Traditional Chinese Medicine : Problems And Drawbacks (2004)

71. Review Of Adverse Effects Of Chinese Herbal Medicine And Herb-Drug Interactions (2004)

72. Pemanfaatan Tumbuhan Ubat Dalam Upaya Pemeliharaan Kesihatan (2015)

73. Peralatan Penyediaan Ubatan Dalam Kaedah Rawatan Perubatan Tradisional Melayu (2015)

74. Amalan Perubatan Tradisional Melayu Di Semenanjung Malaysia : Adakah Masih Relevan Pada Masa Kini (2015)

75. Trend Penggunaan 18 Speseies Tumbuhan Ubatan Di Bawah Progeam NKEA Di Kalangan Pengamal Perubatan Tradisional Melayu Di Semenanjung Malaysia. (2015)

76. Penggunaan Herba Dalam Perbidanan Tradisional Melayu Selepas Bersalin Di Zon Tengah, Semenanjung Malaysia (2015)

77. Penggunaan Tumbuhan Dalam Kehidupan Orang Asli Kumpulan Senoi Di Malaysia : Khususnya Subetnik Temiar Dan Semai (2015)

78. Tapak Warisan FRIM : Potensi Sebagai Tapak Konservasi Ex Situ Terbesar Bagi Germplasma Tumbuhan Ubatan Di Semenanjung Malaysia. (2015)

79. Konservasi Secara Ex Situ Bagi Kacip Fatimah Variety Lanceolate (2015)

80. Rumpai Miang Mexico, Ancaman Melebihi Manfaat (2015)
Medicine

Herbal and Traditional Medicine

Herbal and Traditional Medicine

Herbal and Traditional Medicine

Herbal and Traditional Medicine

Herbal and Traditional Medicine

Herbal and Traditional Medicine

Herbal and Traditional Medicine

Herbal and Traditional Medicine

Herbal and Traditional Medicine

Herbal and Traditional Medicine

Herbal and Traditional Medicine

Herbal and Traditional Medicine

Herbal and Traditional Medicine

Herbal and Traditional Medicine

Herbal and Traditional Medicine

Herbal and Traditional Medicine

Herbal and Traditional Medicine

Herbal and Traditional Medicine

Herbal and Traditional Medicine

Herbal and Traditional Medicine

Herbal and Traditional Medicine

Herbal and Traditional Medicine

Herbal and Traditional Medicine

Herbal and Traditional Medicine 
81. Produk Herba Dan Trend Pencemaran Mikroorganisma (2015)

82. Serangan Atteva Sciodoxa (Ulat Harimau Pada Tanaman Tongkat Ali Di Hutan Dan Ladang Semenanjung Malaysia (2015)

83. Pembiakan Aksesi Kacip Fatimah Terpilih Melalui Kaedah Keratin Dan Penilaian Pengeluaran Pucuk Pada Peringkat Tapak Semaian (2015)

84. Pengeluaran Dan Penilaian Minyak Daun Kayu Manis Malaysia (2015)

85. Pemilihan Dan Penghasilan Baka Limau Purut (Citrus Hystrix Bermutu Tinggi (2015)

86. Mekanisma Tindakan Sebatian Bioaktif Anti-Malaria Dalam Paku Pakis Ubatan, Gleichenia Truncate (2015)

87. Asas Molekul Aktiviti Anti-Maleria Kurkumin (2015)

88. Penilaian Kandungan Fitokimia Dan Aktiviti Sitotoksiti Spesies Terpilih Tumbuhan Ubatan Berasaskan Pengetahuan Traditional Subetnik Jahal/Temiar Di Kg.Air Banun, Gerik, Perak (2015)

89. Penentuan Julat Eurycomanone Dalam Produk Tongkat Ali Melalui Kaedah Kromatografi Cecair Ultraprestasi (2015)

90. Kandungan Fitokimia Mas Cotek Berlainan Aksesi (2015)

91. Saringan Fitokimia Dan Aktiviti Anti-Radang Tumbuhan Ubatan, Terpilih Warisan Orang Asli Semelai, Pos Iskandar, Bera Pahang. (2015)

92. Mengangkat Tongkat Ali Ke Mata Dunia : Pengalaman Pengkomersialan (2015)

93. Kajian Rantaian Nilai Industry Herba Terpilih Di Semenanjung Malaysia (2015)

94. Penyelidikan Dan Pembangunan Serta Pengkomersialan Produk Berasaskan Tanaman Ubatan Dan Beraroma Di Mardi (2015)

95. Peralatan Dalam Perubatan Tradisional Melayu : Khazanah Ilmu Dan Peradaban Warisan Bangsa. (2015)

96. Pendokumenan Pengetahuan Tradisi Melayu Berkaitan Tumbuhna Ubatan Di Semenanjung Malaysia (2015)

97. Hala Tuju Industry Herba Di Bawah NKEA (2015)

98. Memartabatkan Pengetahuan Tradisi : Antara Khazanah Warisan Bangsa Dan Sumber Kekayaan Baharu Negara (2015)

99. Trend Penanaman Dan Kegunaan Tumbuhan Herba Dalam Kalngan Masyarakat Melayu Di Balik Pulau Pinang. (2015)
Herbal and Traditional Medicine

Herbal and Traditional Medicine

Herbal and Traditional Medicine

Herbal and Traditional Medicine

Herbal and Traditional Medicine

Herbal and Traditional Medicine

Herbal and Traditional Medicine

Herbal and Traditional Medicine

Herbal and Traditional Medicine Chemistry

Herbal and Traditional Medicine

Herbal and Traditional Medicine

Herbal and Traditional Medicine

Herbal and Traditional Medicine

Herbal and Traditional Medicine

Herbal and Traditional Medicine

Herbal and Traditional Medicine

Herbal and Traditional Medicine

Herbal and Traditional Medicine

Herbal and Traditional Medicine

\begin{tabular}{clc}
\hline \multicolumn{2}{c}{ PhD Thesis } & \multicolumn{1}{c}{$\begin{array}{c}\text { Disciplines of } \\
\text { Knowledge }\end{array}$} \\
\hline 1. & $\begin{array}{l}\text { Phytochemistry And Pharmacology Of Plants From The } \\
\text { Ginger Family, Zingiberaceae. }\end{array}$ & $\begin{array}{c}\text { Chemistry } \\
\text { Pharmacology }\end{array}$ \\
2. $\begin{array}{l}\text { From Ancient Islamic Samarkand To Andalusia To } \\
\text { American Medicine (2014) }\end{array}$ & $\begin{array}{c}\text { Herbal and Traditional } \\
\text { Medicine }\end{array}$ \\
\hline
\end{tabular}


3. Istilah Tumbuh-Tumbuhan Dalam Al-Quran Al-Karim : Islamic Studies Kajian Leksikografi Dan Analisis Wacana Bahasa Arab (2015)

\begin{tabular}{clc}
\hline \multicolumn{1}{c}{ Master Dissertation } & $\begin{array}{c}\text { Disciplines Of } \\
\text { Knowledge }\end{array}$ \\
\hline 1. & $\begin{array}{l}\text { Factors Influencing Intention To Consume Herbal } \\
\text { Supplement (2004) } \\
\text { 2. } \begin{array}{l}\text { Jenis Jenis Tanaman Herba Ubatan Tempatan Dan Nilai } \\
\text { Perubatannya (2001) }\end{array}\end{array}$ & $\begin{array}{c}\text { Herbal and Traditional } \\
\text { Medicine } \\
\text { Botanical }\end{array}$ \\
\hline \multicolumn{1}{c}{ Micrographs } & $\begin{array}{c}\text { Disciplines Of } \\
\text { Knowledge }\end{array}$ \\
\hline 1. & $\begin{array}{l}\text { Secretory Structures Of Aromatic And Medicinal Plants : } \\
\text { A Review And Atlas Of Micrographs (2000) }\end{array}$ & Agriculture \\
\hline
\end{tabular}

The Disciplines of Knowledge Involved In the Study of Herbs

Based on the study of the herbs classification, analyses of the results are as follows:

Table 2. Classification of research on herbs

\begin{tabular}{clcc}
\hline No. & Disciplines of Knowledge & Frequency & $\begin{array}{c}\text { Percentage } \\
\mathbf{\%}\end{array}$ \\
\hline 1. & Agriculture & 8 & 5.3 \\
2. & Herbal and Traditional Medicine & 82 & 54 \\
3. & Chemistry & 7 & 4.6 \\
4. & Food Science Technology & 9 & 5.9 \\
5. & Botanical & 9 & 5.9 \\
6. & Biology Science & 10 & 6.6 \\
7. & Medicine & 8 & 5.2 \\
8. & Pharmacology & 4 & 2.6 \\
9. & Forest Research & 8 & 5.2 \\
10. & Islamic Studies & 6 & 3.9 \\
\multicolumn{2}{r}{ Total } & 151 & 100 \\
\hline
\end{tabular}




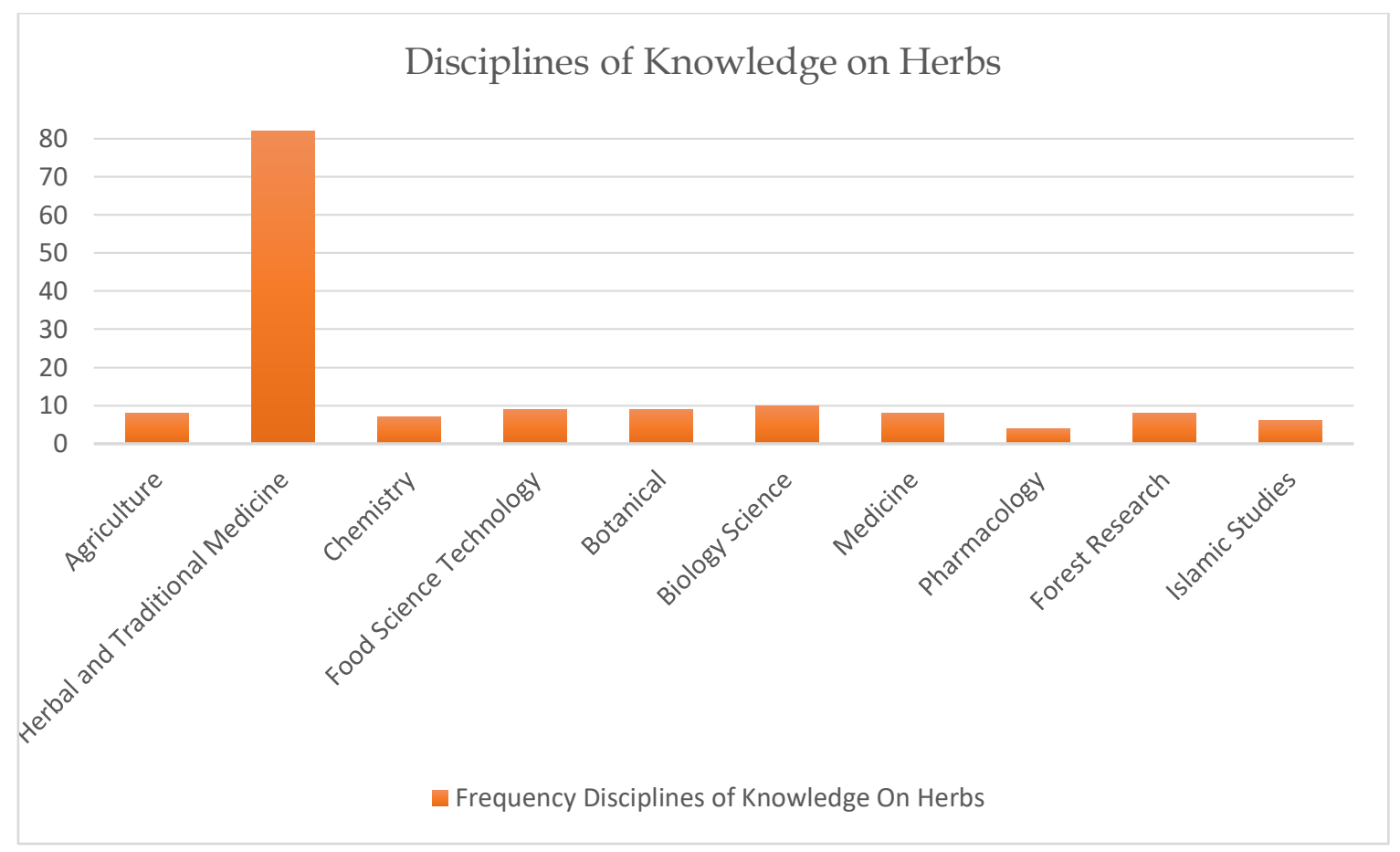

Figure 2. Disciplines of knowledge on herbs

Research on the method of analysis conducted in the previous studies found that most studies on herbs done on a scientific analysis (laboratory studies). Studies on aspects of science has been divided into eight areas that is agriculture, herbal and traditional medicine, chemistry, food science technology, botanical, biological science, medicine and pharmacology which focus on scientific discussion. Meanwhile, for forest research more on new research and survey data on herbs and only one field that focuses on the analysis of herbal-based Islamic studies and manuscripts.

Through comparative evaluation of research found that a total of 137 kinds of studies involves the study of the scientific aspects compared to only 8 studies based on forest research and 6 studies based on Islamic studies. While search keywords give the results of traditional and herbal medical studies the highest, they are still dominated by laboratory studies. Therefore, this proves that scientific research on herbs is too much in line with the requirements of today's science that requires scientific proof and not just a mere theory. The study of herbs from the Islamic point of view is still little in the research and discussion about it from the standpoint of Islam are strongly encouraged. Therefore, it proves that scientific research on herbs is well known and needed by researchers and not just theoretical knowledge solely.

\section{Aspect of Study and Advanced Research on Herbs}

Many studies have been presented on the use of herbs to treat diseases and one of them is the medical Malay manuscript that is the Kitab Tib. Basically in Kitab Tib contains the way to know the disease, general tips for health, chronic diseases such as typhoid and cancer, common illnesseses such as fever, medication and methods of treatment and cure of disease. Most of this knowledge is obtained when parts of plants such as leaves, roots, stems, flowers are used as food and medicines and animal behavior are observed to determine whether certain plants are poisonous or not. From the experience, humans use a variety of nourishment from nature. For instance, ginger in treating fever, onions treat leprosy, lime to cleanse the scalp and eliminate unpleasant smells on the body as well as others (Aniza, 2001:45).

Therefore, it has become essential and important to organize and orderly collection of information regarding herbs. Through the organized information, it may raise awareness among 
the community about the potential of herbs due to the lack of detailed information related to it, as practiced by the Chinese and Indian communities.

Scientific researches have shown that some species of herbaceous plants already containing organic compound and have become an alternative medicine. Among researchers from Universiti Putra Malaysia have found a new technology to prevent early cervical cancer by using Zingiber Zerumbet Smith or known as 'lempoyang' wild ginger. The studies that have undergone clinical trials can provide therapeutics to kill cancer cells without damaging normal tissues (AlZubairi, Abdul, \& Syam, 2017:45). It has been shown to have anti-cancer and opoptosis-inducing properties against various human tumour cells. The rhizomes of the plants are employed as a traditional medicine for some ailments and as condiments. Through this discovery, it benefits for the cervical cancer patient which it can reduces the cost of treatment compared use the imported medicines and is ideally using with the chemotherapy treatment. (UPM's CCD, 2017).

Research and documentation of knowledge about herbs is very important in terms of the development of modern products. With comprehensive data analysis, further investigations of herbs as potential medicines, therapeutics and cosmetics can be achieved. For example, the discovery of anticancer compounds from several species of tropical forest plants by $\mathrm{Dr}$ Azimahtol Hawariah Lope Pihie of the Department of Biochemistry of the National University of Malaysia, has proven that the plant also has high efficacy and high medical value including as an anticancer agent (Nor, 1999). Based on these reasons, the effort to produce scientific data is something that needs to be emphasized in highlighting herbs as an alternative treatment and creating public awareness of the potential of this plant.

In addition, research on herbal plants should also be expanded to create a collaborative network and raising awareness about the potential of this field for creating sustainable economic growth. Most studies only cover a specific field whereas if the cooperation is carried out it can be beneficial to many parties. Among the organizations conducting research while preserving herbs are Malaysian Research and Agriculture Institutions (MARDI), Forestry Institutions Malaysia (FRIM) and Universiti Putra Malaysia (Mohammad \& Hamid 2014). In addition, the knowledge of this herb can also be inherited to future generations so that we do not lose the knowledge that brings great potential for us.

The combination of research on herbs from the aspects of science and religion should be intensified which would prove the truth of the Islamic teachings with the analysis of scientific evidence. In the Holy Quran and hadith mentioned many herbs and treatment systems that can cure diseases. Through the scientific methods, it can be benefit to identify herbs that can be used as medicine and have a safe use of pharmaceuticals. Additionally, it can prevent incidents of poisonous and toxicity and ensure the quality of traditional medicines (Hamamah, 2017:11).

\section{CONCLUSION}

Herbs are natural commodities that have not yet been investigated. The benefit to mankind, it is undeniable. Several proposals for new research on herbal are expected to inspire in producing something useful. If no effort is taken to maintain herbaceous plants, we will lose a very valuable knowledge civilization. So research on herbs by commercially needs to be done and the pharmaceutical results have to be pattern.

\section{ACKNOWLEDGMENT}

Hence, the efforts of researchers from Universiti Sains Islam Malaysia through grants USIMC PPP/UCG-0116/FPQS/30/14316 entitled "In-Depth Analysis Studies of Zingiber Zerumbet According To Al-Quran, Al hadith and Old Malay Manuscript Into Scientific Research Towards Dengue Protease" very significant in the development of knowledge. Further research on herbs is expected to produce something for the benefit of researchers in the Asian region. 


\section{REFERENCES}

Ahmad, K., Monika, M. Y., \& Yakob, A. (2016). Kajian Bibliometrik Terhadap Bahan Penerbitan Penyelidikan Berkaitan Delima : Ke Arah Penyelidikan Terkini Dalam Bidang Pengajian Islam

Al-Zubairi, A. S., Abdul, A. B., \& Syam, M. M. (2017). Evaluation Of The Genotoxicity Of Zerumbone In Cultured Human Peripheral Blood Lymphocytes. Retrieved May 18, 2017 from website www.repository.um.edu.my.

Aniza, N. (2001). Jenis-Jenis Tanaman Herba Ubatan Tempatan dan Nilai Perubatan, Universiti Sains Malaysia.

Glanzel, W., \& Schoepflin, U. (1999). A bibliometric study of reference literature in the sciences and social sciences. Information Processing \& Management, Vol.35, no.1: 31-44.

Hamamah, F. (2003). Potensi Tumbuh-Tumbuhan Sebagai Ubat-Ubatan in Jurnal Elektronik Fakulti Sains Sosial dan Kemanusiaan, and published again in Arkib Archive Jurnal E-Bangi : Universiti Kebangsaan Malaysia.

Hertzel, D. H (2003). "Bibliometrics History" in Drake, Miriam A. (Ed) Encyclopedia Of Library And Information Science, Vol 1, New York : Marcel Dekker.

Hj Zainal, H. (2008). Malaysian Biomedical And Health Sciences Publications In The Database 1990 To 2005 : A Bibliometric Study, Faculty Of Computer Science And Information Technology, University Of Malaya : Kuala Lumpur.

Hobbs, C. (2017). An Outline Of The History Of Herbalism An Overview And Literature Resource List. Retrieved September 7, 2017 from website http://www.healthy.net.

Mat Amin, A. R. (2015). Pengenalan Kepada Penggunaan Herba Dan Tumbuh-Tumbuhan Dalam Rawatan Penyakit Jasmani, Universiti Kebangsaan Malaysia : Bangi.

Mat Piah, H. (2012). Ilmu Perubatan Melayu Tradisonal Dari Naskhah-Naskhah Lama. Jurnal Antarabangsa Alam dan Tamadun Melayu (Iman), 3(3) Universiti Kebangsaan Malaysia : Bangi.

Mohammad, H., \& Hamid, F. A (2008). Manuskrip Perubatan Melayu Islam Di Fatani : Ulasan Terhadap Manuskrip Kitab Tayyib Al-Ihsan Fi Tibb Al-Insan Karya Syeikh Ahmad Al-Fatani. Journal of Al-Tamaddun V3, Universiti Malaya: Kuala Lumpur.

Nor, S. M (1999). Tumbuhan Tropika Penawar Penyakit. Majalah Jelita. Bil. 274.

Omar. A. (2007). "Karya Ilmiah Wadah Ilmu Masyarakat," Akhbar Sinar Harian on 14 May 2007. Retrieved Jun 23, 2017 from website www.sinarharian.com.

Pitchard, A (1969). "Statistical Bibliography Or Bibliometrics?" in Journal Of Documentation, Vol.25 (4).

Plate, K., \& K. Srinivasan (1997). Plant Foods In The Management Of Diabetes Mellitus : Vegetables As Potential Hypoglycaemic Agents. Nahrung 41, Nr. 2: S.

Sahih Al-Bukhari 5687, In Book of Medicine Reference : Book 76, Hadith 10, Vol 7, Book 71, Hadith 591. Retrieved August 16, 2017 from https://sunnah.com/bukhari/76.

Sallau, M. S. K. (2009). Phytochemical And Pharmacological Studies Of The leaves Of Commiphora Kerstingii Engl (Burseraceae), Department Of Pharmaceutical And Medicinal Chemistry, Faculty of Pharmaceutical Sciences, Ahmadu Bello University : Zaria-Nigeria.

Soepadmo, E. (1999). Botanical Study Of Malaysian Medicinal Plants, Forest Research Institute Malaysia (FRIM) : Kuala Lumpur.

Sulistyo-Basuki (2002). Bibliometrics, Scientometrics Dan Informetrics in Kumpulan Makalah Kursus Bibliometrik. Depok : Pusat Studi Jepang. 
The Quran (2008) in Surah: (17: 91), (80: 28), (2: 266), (2: 61), (2: 61), (21: 47), (31: 16), (95: 1), (6: 99 \& 141), (55: 68), (76: 17).Retrieved August 21, 2017 from http://quran.com.

UPM's Corporate Communication Division (CCD) (2017). This news is provided by the Media Section, UPM Creates Products to Prevent Cervical Cancer from Forest Herbs. Retrieved August 3, 2017 from website http://www.upm.edu.my/print. 